\title{
TIPOLOGI FONOLOGIS PADA BAHASA WEBINAR BIDANG PENDIDIKAN (KAJIAN FONOLOGI GENERATIF)
}

\author{
Sudjalil, Gigit Mujianto, Rudi \\ Prodi Pendidikan Bahasa Indonesia, Fakultas Keguruan dan Ilmu Pendikan, \\ Universitas Muhammadiyah Malang, Jl. Raya Tlogomas No. 246, Malang, Jawa Timur, \\ Indonesia \\ sudjalil_63@yahoo.com
}

\begin{abstract}
ABSTRAK: Dilaksanakannya penelitian melalui pendekatan fonologi generatif ini bertujuan mendeskripsikan proses dan kaidah fonologis bahasa webinar khususnya bidang pendidikan. Metode penelitian yang digunakan deskriptif kualitatif, sedangkan analisis datanya menggunakan model analisis Mile Huberman. Sumber data penelitian ini adalah empat rekaman video webinar. Data penelitian berupa kata yang secara fonetis merepresentasikan tipologi fonologis bahasa webinar. Hasil penelitian ini menunjukkan bahwa proses fonologis meliputi 1) asimilasi bertipe regresif, total, parsial, dan langsung, 2) pelemahan bunyi bertipe aferesis, sinkop, dan apokop, sedangkan penguatan bunyi bertipe protesis, epentesis, paragog, dan peluncuran, 3) netralisasi terjadi pada perubahan fonetis bunyi [b] menjadi bunyi [p], dan bunyi [d] menjadi [t] terjadi pada suku kata akhir (koda), 4) disimilasi terjadi secara langsung yang ditandai berubahnya deret konsonan [jj] menjadi [rj], deret konsonan [tt] menjadi [pt], deret konsonan [rr] menjadi [l], dan deret konsonan [II] menjadi [j], 5) metatesis terjadi karena perubahan letak bunyi KKV dalam silabel menjadi KVK. Pengaidahan fonologis didasarkan fitur distingtif fonem dan penggunaan notasi fitur distingtif.
\end{abstract}

KATA KUNCI: bahasa webinar; fonologi generatif; tipologi

\section{PHONOLOGICAL TYPOLOGY IN THE WEBINAR LANGUAGE OF EDUCATION (STUDY OF GENERATIVE PHONOLOGY)}

\begin{abstract}
This current generative phonology study is aimed at describing the processes as well as the phonological patterns of webinar language, specifically in the education field. Descriptive qualitative design was employed; the data analysis was conducted by means of Miles Huberman model. The data were collected from the webinar recordings. Data in the form of words that phonetically represent phonological typologies of webinar language. It has been revealed that the phonological processes include 1) assimilation with the types of regressive, total, partial, and direct; 2) sound attenuation with the types of apheresis, syncope, and apocope; while sound reinforcement is evident by means of prosthesis, epenthesis, paragoge, and gliding; 3) neutralization from the sound of [b] into [p], and the sound [d] into [t] in the last syllable (coda); 4) dissimilation that occurs directly demonstrated by the alteration of consonant cluster [jj] into [rj], consonant cluster [tt] into [pt], consonant cluster [rr] into [l], and consonant cluster [ll] into [j]; 5) metathesis occurs due to the alteration of sound position of CCV into CVC in a syllable. Phonological patterns are based on phoneme distinctive features and the use of distinctive feature notation.
\end{abstract}

KEYWORDS: webinar language; generative phonology; typologies

\begin{tabular}{llll}
\hline Diterima: & Direvisi: & Distujui: & Dipublikasi: \\
2021-07-08 & 2021-07-08 & 2021-07-13 & 2021-10-29
\end{tabular}

Pustaka : Sudjalil, S., Mujianto, G., \& Rudi, R. (2021). TIPOLOGI FONOLOGIS PADA BAHASA WEBINAR BIDANG PENDIDIKAN (KAJIAN FONOLOGI GENERATIF). Fon: Jurnal

Pendidikan Bahasa dan Sastra Indonesia, 17(2), 216-233.

doi:https://doi.org/10.25134/fon.v17i2.4442 


\section{PENDAHULUAN}

Eksistensi bahasa Indonesia di masyarakat pada musim pandemi covid19 ini sangat beragam. Penyebabnya adalah komunikasi antarpenutur tidak dilaksanakan secara bersemuka, sehingga penutur bahasa dalam beraktivitas menggunakan saluran lain (Dani \& Mediantara, 2020: 98). Disadari sepenuhnya oleh semua penutur bahwa pembatasan jarak sosial (social distance) menyebabkan komunikasi tidak bisa berjalan secara efektif. Akan tetapi, Bahasa Indonesia tetap menjadi bahasa utama yang digunakan oleh masyarakat dalam berbagai persoalan kehidupan. Hal ini dapat ditegaskan bahwa bahasa Indonesia memiliki fungsi yang sangat dominan dalam kehidupan ini terutama sebagai alat pengungkap ide, pikiran, gagasan, serta perasaan penuturnya. Yule (1996: 78) mengatakan bahwa fungsi bahasa di salah satu sisi sebagai fungsi interaksi, di sisi yang lain sebagai alat untuk meningkatkan hubungan sosial. Sebelum diberlakukan pembatasan jarak sosial karena persoalan wabah ini, masyarakat Indonesia dapat melakukan seminar atau kegiatan lain dengan menggunakan bahasa Indonesia tanpa ada jarak interaksi antara penutur satu dengan lainnya.

Laman menjadi solusi pilihan yang terbaik untuk mengatasi persoalan ini, sehingga kegiatan webinar akhir-akhir ini banyak muncul di media sosial yang meliputi berbagai bidang kehidupan manusia mulai dari pendidikan, politik, hukum, sosial budaya, ekonomi, kesehatan, atau yang lainnya. Seiring perkembangan zaman, teknologi semacam ini sudah mulai menjadi solusi efektif untuk mengatasi berbagai masalah kehidupan, tak terkecuali di dunia pemasaran dan penyebaran informasi. Saat ini, webinar adalah salah satu media yang mulai digunakan untuk membagikan informasi (Wibowo, Sudan, \& Wirza,
2020: 419). Webinar sebenar kependekan dari web seminar, yaitu seminar yang dilakukan melalui situs web atau aplikasi berbasis internet (Astini, 2020: 248). Teknik seminar ini memungkinkan pembicara membagikan materi melalui media elektronik maupun internet. Jika diamati, interaksi yang dilakukan peserta melalui webinar ini memunculkan berbagai variasi perubahan bunyi mereka. Variasi perubahan bunyi oleh penutur ini merupakan hal yang menarik diamati dalam webinar, karena penuturnya sangat hiterogen baik dilihat dari sisi keilmuan, usia, jenjang akademis, pengalaman, dan kemampuan berbahasa.

Untuk merumuskan variasi perubahan bunyi tersebut kajian fonologi generatif sangatlah relevan digunakan. Chomsky (1972: 85) mengemukakan bahwa teori generatif transformatif merupakan teori modern yang paling menonjol yang mencerminkan kemampuan akal, membicarakan masalah kebahasaan dan pemerolehannya, serta hubungannya dengan akal dan pengetahuan manusia. Menurut teori ini, kapasitas genetik manusia sejak lahir juga memengaruhi kemampuannya untuk memahami bahasa di sekitar sehingga hasilnya adalah sebuah kontruksi sistem bahasa yang tertanam dalam diri. Pendekatan fonologi generatif dapat digunakan untuk merepresentasikan kembali aspek fonetis penutur bahasa yang dilandasi oleh kompetensi yang dimiliki oleh penutur asli untuk dapat menghasilkan dan memahami tata bunyi bahasa mereka. Dalam fonologi generatif, bunyi khas suatu bahasa (fonem-fonem) ditampilkan sebagai kelompok-kelompok fitur suara atau fitur distingtif fonetis. Setiap suara ditampilkan sebagai serangkaian fitur yang berbeda.

Sementara itu, Noam Chomsky (Periksa Lyons, 1984; Suparno, 2002) mengemukakan bahwa bahasa terbentuk karena dua struktur, yakni struktur dalam dan struktur permukaan. Pembagian 
struktur inilah yang kemudian dipakai sebagai dasar untuk kegiatan analisis bahasa secara transformasional. Struktur dalam adalah tempat terjadinya proses berbahasa yang sesungguhnya atau secara mentalistik, sedangkan struktur permukaan adalah wujud lahiriah yang ditransformasikan dari lapis batin. Di dalam tatabahasa transformasi, bahasa yang sifat alamiah baik lisan atau tulis digunakan sebagai dasar untuk menentukan batas bahasa. Bahasa alami (natural language) dibatasi sejumlah bunyi di dalamnya, dalam bahasa tulis terkait alfabet dan perbedaan kalimat dalam suatu bahasa disebabkan oleh urutan bunyi.

Berdasarkan paparan di atas, kajian fonologi generatif terhadap bahasa pada webinar bidang pendidikan yang berasal dari representasi fonetis penutur dapat diketahui atau dipulihkan kembali bentukbentuk asalnya. Untuk mengadakan pemulihan bentuk asal, Schane (1973: 49) menjelaskan bahwa fonologi generatif membicarakan proses-proses dan kaidahkaidah fonologis. Selanjutnya, Schane mengklasifikasikan proses fonologi menjadi empat macam yakni: 1) asimilasi, 2) struktur kata, 3) pelemahan dan penguatan, serta 4) netralisasi. Sementara itu, Yulianto (2019: 35) menggolongkan proses fonologis yang terjadi pada tuturan anak menjadi empat, yaitu 1) proses substitusi meliputi: penghambatan, pengedepanan, peluncuran, vokalisasi, dan netralisasi vokal, 2) proses asimilasi meliputi: penyuaraan, harmonisasi konsonan, dan asimilasi vokal progresif, dan 3) proses struktur silabis meliputi: reduksi kluster, penghilangan konsonan akhir, penghilangan suku tak bertekanan, dan reduplikasi.

Mengingat webinar adalah laman seminar yang diadakan melalui sambungan internet, saat ini ada berbagai aplikasi telekonferensi yang bisa digunakan untuk melakukan seminar sesuai topik, pembicara, waktu dan durasi webinar, serta jumlah peserta diharapkan. Analisis bunyi-bunyi yang digunakan oleh penutur bahasa di webinar menarik untuk diteliti agar rumusan teoritik terkait dengan perkembangan kajian fonologi generatif transformasi dapat dideskripsikan. Penelitian ini akan menghasilkan konsep fonologi generatif dalam bahasa webinar. Data-data kajian dalam penelitian ini sangat berguna untuk mendeskripsikan perubahan bunyi bahasa dalam kata yang digunakan penutur bahasa dalam kegiatan webinar dan sekaligus dapat dipakai sebagai data kajian dalam matakuliah Fonologi Bahasa Indonesia, penelitian pemerolehan bahasa, ataupun penelitian bahasa daerah. Mengingat penelitian ini sangat besar manfaatnya bagi para pakar bahasa, praktisi bahasa, atau pemerhati bahasa Indonesia.

Berbagai penelitian perihal fonologi generatif sudah dilakukan oleh beberapa peneliti. Pertama, oleh Sela \& Nurhayati (2020) dengan judul "Proses Asimilasi pada Bahasa Sumbawa: Fonologi Generatif." Penelitian tersebut bertujuan mendeskripsikan proses asimilasi pada bahasa Sumbawa. Hasil penelitian menyatakan bahwa asimilasi yang terjadi pada bahasa Sumbawa, yaitu (1) penambahan bunyi $/ \mathrm{n} /$, dan (2) pelepasan bunyi di awal, tengah, dan akhir. Proses asimilasi tersebut dilakukan oleh penutur dengan tujuan mempermudah dan menghemat pengucapan.

Kedua, penelitian oleh Nafisah (2017) dengan judul "Proses Fonologis dan Pengkaidahannya dalam Kajian Fonologi Generatif." Tujuan penelitian tersebut mendeskripsikan proses perubahan fonologis terhadap beberapa bahasa, yaitu bahasa Indonesia, Jawa, Arab, dan Zoque. Hasil penelitian menyimpulkan bahwa proses fonologis yang terjadi pada beberapa bahasa tersebut, yaitu penambahan bunyi, 
pelepasan bunyi, koalisi, dan asimilasi. Proses fonologis dapat terjadi, karena adanya penambahan imbuhan.

Selain itu, berdasarkan hasil penelusuran peneliti belum menemukan penelitian yang menggunakan objek webinar sebagai kajian tentang proses dan kaidah fonologis. Adapun penelitian yang mengkaji tentang webinar secara umum dilakukan oleh beberapa peneliti. Pertama, oleh Tarmini, Safi'i, Witdianti, \& Larassaty (2020) dengan judul "Peningkatan Kompetensi Profesional Guru Melalui Webinar Evaluasi Hasil Belajar bagi Guru-guru MTs Al-Ma'arif 1 Aimas." Pada penelitian ini mengkaji pemanfaatan webinar (google meet) sebagai pelatihan evaluasi hasil belajar dengan media quizizz bagi Guru MTs. AlMa'arif 1 Aimas. Berdasarkan hasil penelitian menyimpulkan bahwa pemahaman dan kompetensi para Guru MTs. Al Ma'arif 1 Aimas meningkat secara signifikan, yaitu dengan rata-rata awal $25,9 \%$ menjadi $86,6 \%$. Oleh karena itu, kegiatan pelatihan dengan memanfaatkan webinar dapat dijadikan salah satu model pelatihan untuk meningkatkan kompetensi profesional para guru.

Kedua, penelitian oleh Setiana, Supriyatno, \& Rahayu (2021) dengan judul "Inovasi Pembelajaran Bahasa Indonesia Daring Berbasis Mini Webinar." Fokus penelitian terhadap pemanfaatan mini webinar pada pembelajaran bahasa Indonesia di jenjang perguruan tinggi. Hasil penelitian menunjukkan bahwa dengan adanya pembelajaran berbasis mini webinar pada pembelajaran bahasa Indonesia memberikan dampak positif, yaitu melatih kemandirian belajar siswa, menghidupkan pembelajaran daring bahasa Indonesia, dan sumber literasi bagi mahasiswa.

Berdasarkan penelitian terdahulu di atas, mengisyaratkan bahwa: (1) proses fonologis dengan menggunakan pendekatan fonologi generatif belum diuraikan secara detail. Artinya, hasil yang ditemukan pada ranah asimilasi, kolasi, penambahan dan pelepasan bunyi. Berbeda dengan penelitian ini, selain memfokus terhadap proses fonologis, juga mendiskusikan kaidah fonologis. (2) Objek penelitian berbeda, yaitu webinar dengan topik pendidikan. Penelitian ini sangat penting dilakukan untuk mengembangkan konsep fonologi generatif dalam webinar. Oleh karena itu, tujuan penelitian mendiskusikan tentang proses dan kaidah fonologis bahasa webinar khususnya bidang pendidikan.

\section{METODE}

Pendekatan penelitian ini adalah fonologis generatif. Pendekatan fonologi generatif bertujuan untuk menggambarkan pengetahuan kompetensi yang harus dimiliki oleh penutur asli untuk dapat menghasilkan dan memahami tata bunyi bahasa mereka. Fokus kajian dengan model fonologi generatif adalah representasi fonetis atau bisa disebut struktur permukaan fonetis bahasa webinar. Struktur permukaan yang dianalisis didasarkan: (1) struktur permukaan fonologis, (2) kaidah-kaidah transformasi, (3) struktur fonem semantik, dan (4) struktur dalam atau batin.

Metode penelitian ini adalah deskriptif kualitatif. Metode deskriptif digunakan untuk memaparkan data-data penelitian yang sebelumnya diawali dari kegiatan pengumpulan data, mengelompokan data sesuai tujuan penelitian, mengklasifikasikan perubahan bunyi-bunyi dalam kata bahasa Indonesia baik pada proses fonologis dan pengaidahannya serta penyimpulan. (1) penelitian dilakukan secara alamiah dengan cara merekam kegiatan webinar dan mentranskripsikannya hasil rekaman ke dalam tabel transkripsi fonetis, (2) peneliti bertindak sebagai instrumen utama, (4) penelitian dilakukan secara 
deskriptif, artinya menggambarkan data apa adanya tentang proses dan pengaidahan fonologis yang dianalisis terkait dengan segmen bahasa webinar, (5) analisis data penelitian dilakukan secara induktif, artinya dari fakta-fakta dan gejala perubahan bunyi bahasa kemudian disimpulkan, dan lebih menekankan pada proses dan kaidah fonologis, (6) menghidari penggunaan teori atau konsepkonsep yang menyimpang dari permasalahan penelitian, dan (7) rancangan penelitian yang digunakan adalah deskriptif kualitatif.

Data penelitian ini berasal dari hasil pencatatan peneliti mengenai proses dan kaidah fonologis bahasa webinar bidang pendidikan. Data berupa data kualitatif mengenai proses dan kaidah fonologis. Sumber data penelitian ini adalah empat rekaman kegiatan webinar terkait bidang pendidikan. Keempat rekaman video webinar yang dimaksud meliputi video I berjudul Tamaddun Melayu dan Tradisi Kesusastraan direkam 29 September 2020, video II berjudul Strategi Publikasi Artikel di Jurnal Bereputasi direkam 3 September 2020, video III berjudul Finding a Model for Linguistics, Literature, and Philology Research on Dijital Era 4.0 direkam 22 Agustus 2020, dan video IV berjudul Orientasi Daring Penguatan Nilai-Nilai Pancasila dan Moderasi Beragama bagi Komunitas Akademik Dosen dan Mahasiswa direkam 22 Agustus 2020. Keempat rekaman video tersebut kemudian ditranskripsikan ke dalam transkripsi fonetis dalam tabel.

Prosedur pengumpulan data penelitian meliputi beberapa tahapan, yaitu: (1) merekam 4 kegiatan webinar terkait bidang pendidikan, dimulai pada tanggal 23 Agustus sampai 26 September 2020. (2) Mentraskipkan hasil rekaman ke dalam tabel fonetis. (3) Memeriksa dan mengedintifikasi data penelitian. (4) Mengadakan studi pustaka yang bersumber dari buku dan laporan penelitian. Adapun analisis data menggunakan model analisis Milles Huberman. Komponen analisis data yang dimaksudkan meliputi pengumpulan data, penyeleksian data, pemaparan data, dan penarikan kesimpulan atau verifikasi.

\section{HASIL DAN PEMBAHASAN}

Hasil yang dideskripsikan dalam penelitian ini meliputi dua aspek, yakni proses dan kaidah fonologis bahasa webinar bidang pendidikan. Proses fonologi bahasa webinar meliputi: 1) asimilasi, 2) pelemahan dan penguatan, 3) netralisasi, 4) disimilasi, dan 5) proses struktur kata.

\section{Asimilasi}

Asimilasi merupakan proses berubahnya dua bunyi yang berbeda menjadi bunyi yang sama atau hampir sama (mirip) sebagai akibat pengaruh bunyi yang ada di lingkungannya. Proses fonologis pada bentukan kata bahasa webinar menyebabkan terjadinya asimilasi. Data asimilasi regresif yang ditemukan dalam penelitian ini sebagaimana pada tabel 1 berikut ini.

Tabel 1. Proses Asimilasi Regresif

\begin{tabular}{|c|c|c|c|}
\hline $\begin{array}{l}\text { Proses } \\
\text { Fonologis }\end{array}$ & & $\begin{array}{l}\text { Kata } \\
\text { Berasimila } \\
\text { si }\end{array}$ & Makna \\
\hline $\begin{array}{l}\{\mathrm{m} ə \mathrm{~N}- \\
\operatorname{kan}\}+\mathrm{lak} \\
\mathrm{u}\end{array}$ & $\rightarrow$ & $\begin{array}{l}\text { [məlakuka } \\
\text { n] }\end{array}$ & Mengejakan \\
\hline $\begin{array}{l}\{\mathrm{m} ə \mathrm{~N}- \\
\mathrm{i}\}+ \text { milik }\end{array}$ & $\rightarrow$ & [məmiliki] & mempunyai \\
\hline $\begin{array}{l}\{\mathrm{məN}- \\
\text { i }\}+ \text { nikmat }\end{array}$ & $\rightarrow$ & $\begin{array}{l}\text { [mənikmat } \\
\text { i] }\end{array}$ & merasai \\
\hline $\begin{array}{l}\{\mathrm{məN}- \\
\text { kan }\}+ \text { rasa }\end{array}$ & $\rightarrow$ & $\begin{array}{l}\text { [mərasaka } \\
\text { n] }\end{array}$ & menikmati \\
\hline $\begin{array}{l}\{\mathrm{m} ə \mathrm{~N}- \\
\text { kan }\}+ \text { waj } \\
\text { ib }\end{array}$ & $\rightarrow$ & $\begin{array}{l}\text { [məwajibk } \\
\text { an] }\end{array}$ & $\begin{array}{l}\text { mengharusk } \\
\text { an }\end{array}$ \\
\hline
\end{tabular}


Bunyi nasal yang melekat pada konfiks $\{\mathrm{meN}-\mathrm{i}\}$ dan $\{$ meN-kan $\}$ setelah bergabung dengan kata laku, milik, nikmat, rasa, dan wajib, maka bunyi nasal [+nas] menjadi zero [Ø]. Bunyi [nas] pada awalan meN- setelah bergabung dengan bunyi [1], bunyi [m], bunyi [p], bunyi [n], bunyi [r], dan bunyi [w] yang kesemuanya berfitur sonoritas [+son] kemudian menjadi zero [Ø]. Peristiwa ini bisa disebut asimilasi regresif. Asimilasi yang terjadi pada data tersebut termasuk asimilasi langsung karena karena jarak antar segmen berdekatan. Secara sederhana perubahan itu dapat diformulasikan sebagai berikut ini.

Gambar 1. Kaidah Fonologis Perubahan Bunyi [N] Menjadi [Ø]

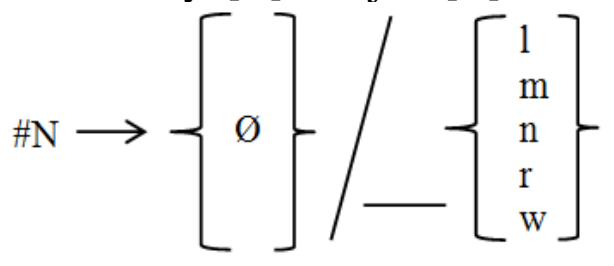

Pembacaan kaidah di atas adalah bunyi nasal [N] sebagai koda dapat berubah menjadi [Ø] setelah bertemu dengan onset yakni bunyi [1], bunyi [m], bunyi [n], bunyi [r], dan [w] yang berada di suku kata berbeda. Formulasi transformasi fonologis sebagai berikut ini.

Gambar 2. Kaidah Fonologis Perubahan Bunyi [N] menjadi [I, m, n, r, w]

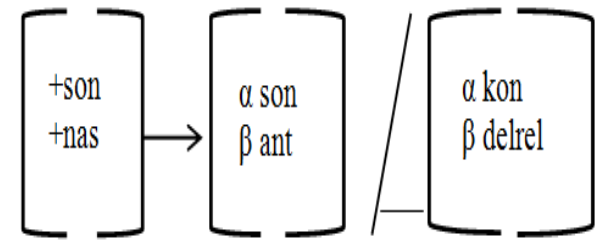

Formulasi tersebut menjelaskan bahwa bunyi $[\mathrm{N}]$ dapat berubah menjadi bunyi [1], bunyi $[\mathrm{m}]$, bunyi $[\mathrm{n}]$, bunyi [r], dan [w] setelah bertemu dengan bunyi [1], bunyi $[\mathrm{m}]$, bunyi $[\mathrm{n}]$, bunyi $[\mathrm{r}]$, dan $[\mathrm{w}]$, akhirnya menjadi [11], bunyi [mm], bunyi [nn], bunyi [rr], dan [ww] kemudian diluluhkan sebagian bunyinya.

Asimilasi parsial juga ditemukan pada bentukan kata sebagaimana pada tabel 2 berikut ini.

Tabel 2. Proses Asimilasi Parsial

\begin{tabular}{|c|c|c|c|}
\hline $\begin{array}{l}\text { Proses } \\
\text { Fonologis }\end{array}$ & & $\begin{array}{l}\text { Kata } \\
\text { Berasimilasi }\end{array}$ & Makna \\
\hline $\begin{array}{l}\{\mathrm{m} ə \mathrm{~N}- \\
\text { kan }\}+ \\
\text { bangkit }\end{array}$ & & $\begin{array}{l}\text { [məmbaykit } \\
\text { kan] }\end{array}$ & $\begin{array}{l}\text { membangu } \\
\mathrm{n} \text { kembali }\end{array}$ \\
\hline $\begin{array}{l}\{\mathrm{məN}- \\
\text { kan }\}+ \text { fasil } \\
\text { itas }\end{array}$ & $\rightarrow$ & $\begin{array}{l}\text { [məmfasilit } \\
\text { asi] }\end{array}$ & $\begin{array}{l}\text { memberika } \\
\mathrm{n} \text { fasilitas }\end{array}$ \\
\hline $\begin{array}{l}\{\mathrm{məN}- \\
\text { kan }\}+ \text { jala } \\
n\end{array}$ & & $\begin{array}{l}\text { [mənjalanka } \\
\mathrm{n}]\end{array}$ & $\begin{array}{l}\text { menggera } \\
\text { kkan }\end{array}$ \\
\hline $\begin{array}{l}\{\mathrm{m} \curvearrowright \mathrm{N}- \\
\operatorname{kan}\}+ \text { gun } \\
\mathrm{a}\end{array}$ & & $\begin{array}{l}\text { [məngunaka } \\
\mathrm{n}]\end{array}$ & memakai \\
\hline $\begin{array}{l}\{\mathrm{məN}- \\
\text { kan }\}+ \text { hasi } \\
1\end{array}$ & & $\begin{array}{l}\text { [məyhasilka } \\
\mathrm{n}]\end{array}$ & $\begin{array}{l}\text { mengeluar } \\
\text { kan hasil }\end{array}$ \\
\hline $\begin{array}{l}\{\text { pəN- } \\
\}+ \text { bantu }\end{array}$ & $\rightarrow$ & [pəmbantu] & penolong \\
\hline $\begin{array}{l}\{\text { pəN- } \\
\text { an }\}+c \text { Ipta }\end{array}$ & $\rightarrow$ & $\begin{array}{l}\text { [poncIptaan } \\
\text { ] }\end{array}$ & pembuatan \\
\hline $\begin{array}{l}\{\text { pəN- } \\
\text { an }\}+ \text { didIk }\end{array}$ & $\rightarrow$ & $\begin{array}{l}\text { [pəndidikan } \\
\text { ] }\end{array}$ & $\begin{array}{l}\text { perubahan } \\
\text { tingkah } \\
\text { laku }\end{array}$ \\
\hline
\end{tabular}

Proses fonologis asimilasi parsial ditemukan pada bahasa webinar pendidikan. Data penelitian terpapar di atas menujukkan terjadinya asimilasi regresif, parsial, dan langsung. Bunyi nasal yang melekat pada konfiks $\{$ meNkan $\}, \quad\{$ pəN-an $\}$, dan $\{$ pəN- $\}$ setelah bergabung dengan kata bangkit, fasilitas, jalan, nikmat, guna, hasil, bantu, cipta 
dan didik, maka mengalami asimilasi, bunyi [+nas] pada awalan tersebut berubah menjadi bunyi $[\mathrm{m}]$, bunyi $[\mathrm{n}]$, dan bunyi [y], sedangan bunyi [b], [f], [j], $[\mathrm{g}],[\mathrm{h}],[\mathrm{b}],[\mathrm{c}]$, dan [d] tidak luluh.

Berdasarkan analisis data di atas dapat dideskripsikan bahwa asimilasi sebagai bagian proses fonologis berupa deret dua konsonan (KK) yang berada dalam suku kata yang berbeda. Bunyi $[\mathrm{N}]$ dapat berubah menjadi bunyi bunyi [m], bunyi [n], dan bunyi [n] setelah mendapat pengaruh dari bunyi konsonan lain setelahnya, yaitu [b], [f], [j], [g], [h], [b], [c], dan [d]. Secara sederhana perubahan itu dapat diformulasikan sebagai berikut ini.

Gambar 3. Kaidah Fonologis Perubahan Bunyi Nasal \#[N] menjadi [m, n, y]

$$
\# N \longrightarrow\left\{\begin{array}{l}
\mathrm{m} \\
\mathrm{n} \\
\mathrm{y}
\end{array}\right] /\left[\begin{array}{l}
\mathrm{b} \\
\mathrm{f} \\
\mathrm{r} \\
\mathrm{g} \\
\mathrm{h} \\
\mathrm{c} \\
\mathrm{c} \\
\mathrm{d}
\end{array}\right]
$$

Pembacaan kaidah di atas adalah bunyi nasal $\#[\mathrm{~N}]$ sebagai koda dapat berubah menjadi $[\mathrm{m}, \mathrm{n}, \mathrm{n}]$ setelah bertemu dengan onset yakni bunyi [b], [f], [j], [g], $[\mathrm{h}],[\mathrm{b}],[\mathrm{c}]$, dan [d] tidak luluh yang berada di suku kata berbeda. Penggambaran kaidah fonologis sebagai berikut ini.

Gambar 4. Kaidah Fonologis Perubahan Bunyi $[\mathrm{N}]$ menjadi $[\mathrm{m}, \mathrm{n}, \mathrm{y}]$
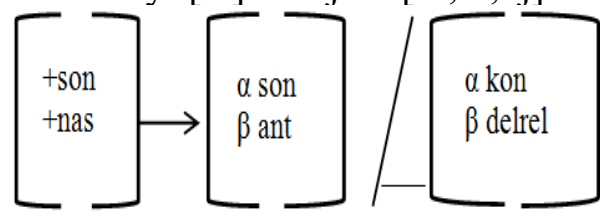

Kaidah ini menyatakan bahwa bunyi $[\mathrm{N}]$ dapat berubah menjadi bunyi [m], bunyi [n], dan [y] setelah bertemu dengan bunyi [b], [f], [j], [g], [h], [b], [c], dan [d].

Asimilasi regresif, parsial, langsung ditemukan dalam penelitian ini seperti pada tabel 3 berikut ini.

Tabel 3. Asimilasi Regresif, Parsial, Langsung

\begin{tabular}{|c|c|c|c|}
\hline $\begin{array}{l}\text { Proses } \\
\text { Fonologi } \\
\mathrm{S}\end{array}$ & & $\begin{array}{l}\text { Kata } \\
\text { Berasimilasi }\end{array}$ & Makna \\
\hline $\begin{array}{l}\{\mathrm{meN}- \\
\text { kan\}+aja }\end{array}$ & & $\begin{array}{l}\text { [məyajarkan } \\
\text { ] }\end{array}$ & $\begin{array}{l}\text { memberi } \\
\text { pelajaran }\end{array}$ \\
\hline $\begin{array}{l}\{\text { meN- } \\
\text { i }\} \text { +alam }\end{array}$ & $\rightarrow$ & [məyalami] & $\begin{array}{l}\text { merasai } \\
\text { peristiwa }\end{array}$ \\
\hline $\begin{array}{l}\{\text { meN- } \\
\}+ \text { inspira } \\
\text { si }\end{array}$ & & $\begin{array}{l}\text { [məyinspira } \\
\text { si] }\end{array}$ & $\begin{array}{l}\text { menimbulk } \\
\text { an inspirasi }\end{array}$ \\
\hline $\begin{array}{l}\{\text { peN- } \\
\text { an }\}+ \text { ala } \\
m\end{array}$ & $\rightarrow$ & [pəyalaman] & $\begin{array}{l}\text { yang } \\
\text { pernah } \\
\text { dialami }\end{array}$ \\
\hline $\begin{array}{l}\{\mathrm{peN}- \\
\text { an }\}+ \text { erti }\end{array}$ & $\rightarrow$ & [pəyərtian] & $\begin{array}{l}\text { Pemahama } \\
\mathrm{n}\end{array}$ \\
\hline $\begin{array}{l}\{\text { peN- } \\
\}+ \text { anut }\end{array}$ & $\rightarrow$ & [pəyanUt] & pengikut \\
\hline $\begin{array}{l}\{\text { meN- } \\
\}+ \text { angkat }\end{array}$ & $\rightarrow$ & [məyankat] & menaikkan \\
\hline $\begin{array}{l}\{\mathrm{meN}- \\
\}+ \text { olah }\end{array}$ & $\rightarrow$ & [məyolah] & berolah \\
\hline $\begin{array}{l}\{\mathrm{meN}- \\
\text { i }\}+\mathrm{ikut}\end{array}$ & $\rightarrow$ & [mənikuti] & menyertai \\
\hline $\begin{array}{l}\{\mathrm{meN}- \\
\}+ \text { elak }\end{array}$ & $\rightarrow$ & $\begin{array}{l}\text { [mənelakny } \\
\text { a] }\end{array}$ & menghindar \\
\hline $\begin{array}{l}\{\mathrm{meN}- \\
\}+ \text { ulas }\end{array}$ & $\rightarrow$ & [məyulas] & $\begin{array}{l}\text { memberi } \\
\text { penjelasan }\end{array}$ \\
\hline
\end{tabular}

Asimilasi yang terjadi pada tabel 3 di atas menunjukkan terjadinya proses fonologis yakni asmilasi regresif, parsial, dan langsung. Asimilasi regresif 
merupakan perubahan bunyi yang menjadi mirip dengan bunyi yang mengikutinya. Hal ini tampak pada berubahnya bunyi $[\mathrm{N}]$ menjadi $[\mathrm{y}]$ setelah bergabung dengan vokal [a], [i], [e], [u], dan [o]. Bunyi [N] luluh sebagai akibat pengaruh bunyi sesudahnya. Jika disederhanakan kaidah transformasi perubahan bunyi sebagai berikut.

Gambar 5. Kaidah Fonologis Perubahan Bunyi Nasal \#[N] Menjadi [y]

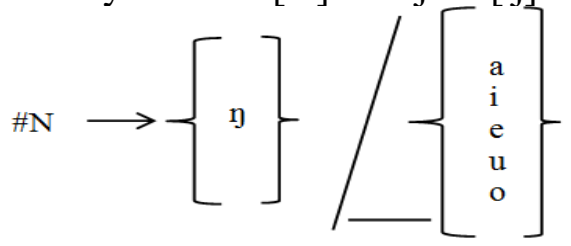

Pembacaan kaidah di atas adalah bunyi nasal $\#[\mathrm{~N}]$ sebagai koda dapat berubah menjadi [y] setelah bertemu dengan onset yakni bunyi [a], [i], [e], [u], [o] yang berada di suku kata kedua sebagai onset. Formulasi transformasi kaidah fonologisnya sebagai berikut ini.

Gambar 6. Kaidah Fonologis Perubahan Bunyi $[\mathrm{N}]$ menjadi [y]

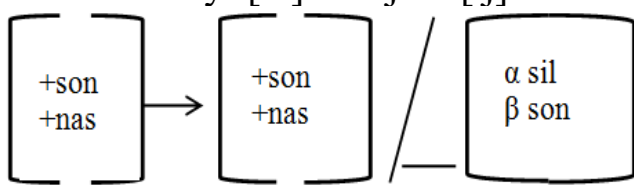

Kaidah ini menyatakan bahwa bunyi [N] dapat berubah menjadi bunyi [y] setelah bertemu dengan bunyi [bunyi [a], [i], [e], [u], [o] dan bunyi [a], [i], [e], [u], [o] dipertahankan sebagai onset (vokal yang menduduki segmen inti dalam suku kata yang letaknya mendahului konsonan).

\section{Pelemahan dan Penguatan}

Selain asimilasi, proses fonologis yang ditemukan meliputi proses pelemahan dan penguatan. Pelemahan ditunjukkan dihilangkannya bunyi di awal kata (aferesis), di tengah kata (sinkop), dan di akhir kata (apokop). Penghilangan sebagian unsur atau bunyi di awal kata bisa disebut aferesis. Pelesapan semacam ini seringkali disebabkan oleh ruas yang menduduki suatu posisi yang lemah dalam suku kata. Munculnya pelemahan pada ruas kata atau kata disebabkan oleh dialek atau tujuan penutur untuk memudahkan pelafalan. Pelemahan atau penghilangan bunyi [s], [b], dan [m] pada kata sudah, sama, saja dan emang sehingga menjadi udah, ama, aja dan emang menunjukkan terjadi proses transformasi.

Kata-kata dalam bahasa webinar yang mengalami pelemahan dalam bentuk aferesis sebagaimana pada tabel 4 berikut ini.

Tabel 4. Pelemahan pada Awal kata

\begin{tabular}{|c|c|c|c|}
\hline \multicolumn{4}{|c|}{ (Aferesis) } \\
\hline $\begin{array}{l}\text { Bentukan } \\
\text { asal }\end{array}$ & & Aferesis & Makna \\
\hline sudah & $\rightarrow$ & [udah] & $\begin{array}{l}\text { terjadi, } \\
\text { selesai }\end{array}$ \\
\hline sama & $\rightarrow$ & [ama] & $\begin{array}{l}\text { tidak berbeda, } \\
\text { serupa }\end{array}$ \\
\hline bisa & $\rightarrow$ & [isa] & $\begin{array}{l}\text { mampu atau } \\
\text { dapat }\end{array}$ \\
\hline saja & $\rightarrow$ & [aja] & Juga \\
\hline emang & $\rightarrow$ & [eman] & sebenarnya \\
\hline
\end{tabular}

Penyederhanaan kaidah transformasi perubahan bunyi pada kata-kata di atas sebagai berikut ini.

Gambar 7. Kaidah Fonologis Pelemahan

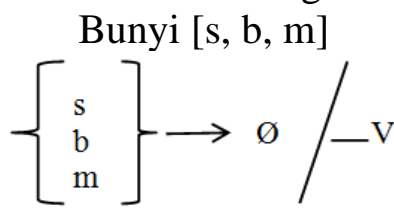

Pembacaan kaidah di atas adalah bunyi $[\mathrm{s}, \mathrm{b}, \mathrm{m}]$ dilemahkan/dilesapkan sebelum vokal pada suku kata pertama. Bunyi [b] berfitur bersuara berubah menjadi [p] berfitur tidak bersuara ketika sebagai koda atau tidak ada bunyi 
setelahnya yang memengaruhi serta berada di suku kata akhir. Formulasi transformasi kaidah fonologisnya sebagai berikut ini.

Pembacaan kaidah di atas adalah bunyi [s, b, m] dilemahkan/dilesapkan sebelum vokal pada suku kata pertama. Bunyi [b] berfitur bersuara berubah menjadi [p] berfitur tidak bersuara ketika sebagai koda atau tidak ada bunyi setelahnya yang memengaruhi serta berada di suku kata akhir. Formulasi transformasi kaidah fonologisnya sebagai berikut ini.

Gambar 8. Kaidah Fonologis Pelemahan Bunyi [s, b, m] Berfitur Konsonan Bersuara

$$
\left[\begin{array}{cc}
\mathrm{K} \rightarrow & \theta / \mathrm{V} \\
\text { +suara } & \\
\text { +sil }
\end{array}\right]
$$

Kaidah ini menyatakan bahwa bunyi $[\mathrm{s}, \mathrm{b}, \mathrm{m}]$ berfitur sebagai konsonan bersuara dilesapkan atau dihilangkan sebelum vokal. Status bunyi yang dihilangkan sebagai koda.

Pelemahan bunyi lainnya juga terjadi di tengah-tengah kata. Data penelitian berikut menunjukkan terjadinya pelemahan bunyi di tengah kata (sinkop). Hal ini dapat dilihat pada tabel 5 berikut ini.

Tabel 5. Pelemahan pada Tengah Kata (Sinkop)

\begin{tabular}{|c|c|c|c|}
\hline $\begin{array}{l}\text { Bentukan } \\
\text { Asal }\end{array}$ & & Sinkop & Makna \\
\hline shastra & $\rightarrow$ & [sastra] & $\begin{array}{l}\text { karya tulis yang } \\
\text { bersifat estetik }\end{array}$ \\
\hline chitra & $\rightarrow$ & [citra] & gambaran \\
\hline tahun & $\rightarrow$ & [taun] & $\begin{array}{lr}\text { masa } & \text { yang } \\
\text { lamanya } & 12 \\
\text { bulan } & \end{array}$ \\
\hline perilaku & $\rightarrow$ & [prilaku] & tanggapan \\
\hline karena & $\rightarrow$ & [karna] & sebab \\
\hline periksa & $\rightarrow$ & [prIksa] & secara \\
\hline
\end{tabular}

teliti

uttama $\rightarrow$ [utama] terpenting

work $\rightarrow$ [wok] kerja

form $\rightarrow$ [fom] bentuk

Pelemahan bunyi [ə], [h], [t], dan [r] di tengah kata merupakan sebagian temuan penelitian terkait dengan proses fonologis pada bahasa webinar bidang pendidikan. Jika ditelusuri lebih dalam lagi dalam rekaman video webinar lainnya pelemahan bunyi semacam ini saja banyak ditemukan. Pelemahan ini dikatakan para pakar bahasa bertujuan memperlancar pelafalan, penyederhaan segmen, dan penghematan. Hal yang penting untuk dipahami adalah pelemahan bunyi dalam suatu bahasa tidak mengubah makna kata yang sebenarnya. Proses transformasi fonologis melalui sinkop ini menunjukkan bahasa webinar memiliki karakteristik tertentu.

Gambar 9. Kaidah Fonologis Pelemahan

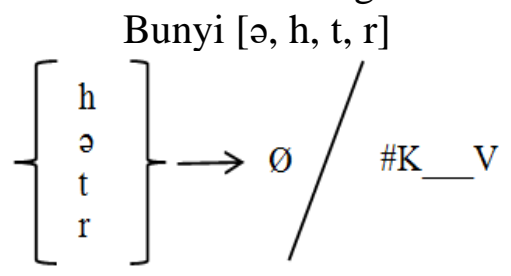

Pembacaan kaidah di atas adalah $\begin{array}{llll}\text { bunyi } \quad[ə], \quad[\mathrm{h}], \quad[\mathrm{t}], & \text { dan } & {[\mathrm{r}]}\end{array}$ dilemahkan/dilesapkan di antara konsonan dan vokal pada suku kata yang berbeda. Formulasi transformasi kaidah fonologisnya sebagai berikut ini.

Gambar 10. Kaidah Fonologis Pelemahan Bunyi [ə, h, t, r] Berfitur Konsonan Bersuara dan Vokal Rendah

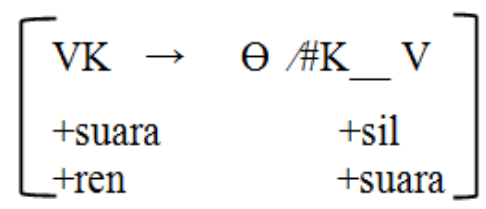

Kaidah ini menyatakan bahwa bunyi [ə], [h], [t], dan [r] berfitur sebagai 
konsonan bersuara dan vokal rendah dilesapkan atau dihilangkan di antara konsonan bersuara dan vokal rendah. Status bunyi yang dihilangkan sebagai koda.

Selain pelemahan di tengah kata, temuan penelitian lainnya adalah pelemahan terjadi di akhir kata pada bahasa webinar bidang pendidikan. Datadata penelitian yang terkait dengan pelemahan bunyi di akhir kata. Kata slide, home, tims, youtube, dan multidisipline merupakan kata-kata yang mengalami penghilangan atau pelemahan bunyi [ə] pada akhir kata. Pada kata-kata tersebut terjadi pelemahan vokal [e] setelah konsonan [d], [m], [b], dan [n]. Bunyi [ə] termasuk vokal rendah, depan dan tidak bulat. Vokal [ə] berfitur [+sil], [-bul], [+ren], dan [-kon]. Peristiwa pelemahan bunyi [ə] pada slide, home, timə, youtube, dan multidisipline merupakan tipe perubahan bunyi apokop. Tujuan utama terjadinya perubahan ini adalah penyederhanaan struktur kata dan pelacaran pelafalan kata. Akibat peritiwa perubahan bunyi ini, struktur bahasa asal menjadi berubah pula. Penghilangan atau pelemahan segmen bunyi di akhir kata ini tidak banyak ditemukan dan kata-kata yang digunakan oleh peserta webinar berasal dari pungutan asing terutama bahasa Inggris. Proses transformasi fonologis melalui apokop ini menunjukkan bahwa bahasa webinar memiliki karakteristik tertentu.

Penguatan atau bisa disebut penyisipan pada bahasa webinar ini terjadi di awal, tengah, dan akhir kata. Pada data berikut ini menunjukkan bahwa terjadi proses fonologis protesis pada bahasa webinar. Data yang ditemukan terkait tipe perubahan bunyi pada kata tidak banyak. Penguatan atau penambahan bunyi [a] dan [ə] pada bentuk asal suatu kata dapat mengubah struktur kata tersebut. Proses transformasi fonologis melalui protesis ini menunjukkan adanya karakteristik tertentu pada bahasa webinar. Penguatan bunyi pada awal kata dapat dilihat pada tabel 6 berikut ini.

Tabel 6. Penguatan pada Awal Kata (Protesis)

\begin{tabular}{lll}
$\begin{array}{l}\text { Bentukan } \\
\text { Asal }\end{array}$ & Protesis & Makna \\
\hline smara $\rightarrow$ [asmara] & $\begin{array}{l}\text { perasaan senang } \\
\text { lawan jenis } \\
\text { bilangan yang } \\
\text { ditandai 4 }\end{array}$ \\
pat $\rightarrow$ [empat] & $\begin{array}{l}\text { zat yang } \\
\text { dihasilkan hati }\end{array}$ \\
pedu
\end{tabular}

Penyederhanaan kaidah transformasi perubahan bunyi pada kata-kata di atas sebagai berikut ini.

$$
\begin{aligned}
& \text { Gambar 11. Kaidah Fonologis } \\
& \text { Penambahan Bunyi [ə, a] } \\
& \Theta \rightarrow\left\{\begin{array}{l}
\mathrm{a} \\
\partial
\end{array}\right\} / \# \ldots \text { K }
\end{aligned}
$$

Pembacaan kaidah di atas adalah bunyi [ə] dan [a] ditambahkan sebelum konsonan pada suku kata yang pertama. Formulasi transformasi kaidah fonologisnya sebagai berikut ini.

Gambar 12. Kaidah Fonologis Penambahan Bunyi [ə, a] Berfitur Vokal Rendan dan Bulat

$$
\Theta \rightarrow\left[\begin{array}{c}
\mathrm{V} \\
+\mathrm{ren} \\
+\mathrm{bul}
\end{array}\right] / \#-\mathrm{K}
$$

Kaidah ini menyatakan bahwa bunyi [ə] dan [a] berfitur sebagai vokal rendah dan bulat ditambahkan sebelum konsonan, status bunyi yang ditambahkan sebagai onset.

Selain itu, penguatan atau penyisipan bunyi di tengah kata juga terjadi pada bahasa webinar sebagaimana dapat dilihat pada tabel 7 berikut ini. 
Tabel 7. Penguatan pada Tengah Kata (Epentesis)

\begin{tabular}{|c|c|c|c|}
\hline \multicolumn{2}{|c|}{$\begin{array}{l}\text { Bentukan } \\
\text { Asal }\end{array}$} & Epentesis & Makna \\
\hline maaf & $\rightarrow$ & ma?af & $\begin{array}{l}\text { permintaan } \\
\text { ampun }\end{array}$ \\
\hline sapaan & $\rightarrow$ & sapa?an & $\begin{array}{l}\text { ajakan untuk } \\
\text { bercakap }\end{array}$ \\
\hline saat & $\rightarrow$ & sa?at & waktu \\
\hline phala & $\rightarrow$ & pahala & $\begin{array}{l}\text { ganjaran dari } \\
\text { Allah }\end{array}$ \\
\hline akasa & $\rightarrow$ & angkasa & lapisan udara \\
\hline chaya & $\rightarrow$ & cahaya & sinar \\
\hline sajak & $\rightarrow$ & sanjak & $\begin{array}{l}\text { karangan } \\
\text { pendek }\end{array}$ \\
\hline upama & $\rightarrow$ & umpa & bagaikan \\
\hline tubuh & $\rightarrow$ & Tumbuh & $\begin{array}{l}\text { hidup menjadi } \\
\text { besar }\end{array}$ \\
\hline bhasa & $\rightarrow$ & bahasa & lambang bunyi \\
\hline
\end{tabular}

Penyisipan bunyi [?], [a], [y], [m], [n] di tengah-tengah kata menunjukkan bahwa terjadi proses fonologis epentesis pada bahasa webinar. Data penelitian yang ditemukan terkait tipe perubahan bunyi ini banyak, baik diserap dari bahasa Sanskerta, Latin, ataupun Arab. Proses transformasi fonologis melalui protesis ini menunjukkan adanya karakteristik tertentu pada bahasa webinar. Penyederhanaan kaidah transformasi perubahan bunyi pada kata-kata di atas sebagai berikut ini.

Gambar 13. Kaidah Fonologis Penyisipan Bunyi [?]

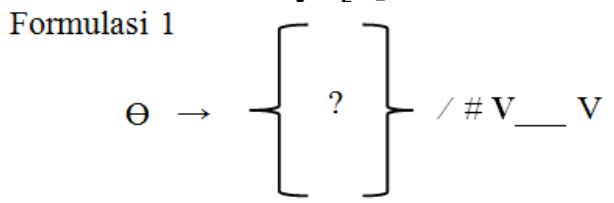

Gambar 14. Kaidah Fonologis Penyisipan Bunyi [a, $\mathrm{y}, \mathrm{m}, \mathrm{n}]$

Formulasi 2

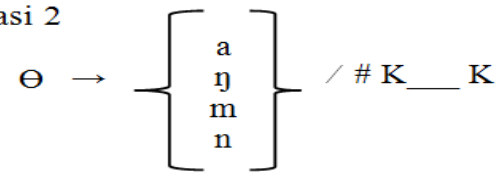

Pembacaan kaidah di atas, pada formulasi 1 terjadi penyisipan bunyi [?] di antara dua vokal rendah bulat, sedangkan pada formulasi 2 terjadi penyisipan bunyi [a], [n], [m], [n] di antara konsonan pada suku kata yang pertama. Kaidah transformasi perubahan bunyi diformulasikan sebagai berikut ini.

Gambar 15. Kaidah Fonologis Penyisipan [?] Berfitur [-son dan -kont]

Formulasi 1

$$
\Theta \rightarrow\left[\begin{array}{c}
\mathrm{K} \\
\text {-son } \\
\text {-kont }
\end{array}\right] / \# \mathrm{~V}-\mathrm{V}
$$

Gambar 16. Kaidah Fonologis Penyisipan Bunyi Vokal [a] Berfitur Rendah Bulat, juga bunyi [n, m, n] Berfitur [+nas]

Formulasi 2

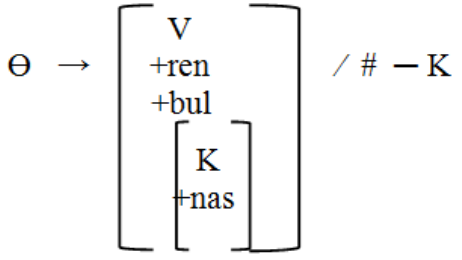

Kaidah ini menyatakan bahwa bunyi [?] berfitur [-son] dan [-kont] disisipkan di antara dua vokal rendah. Pada formulasi 2, bunyi vokal [a] berfitur rendah bulat disisipkan di antara konsonan, juga bunyi [n], [m], [n] berfitur [+nas] disisipkan di antara konsonan.

Selain penguatan di tengah kata, berikutnya di dalam penelitian ini juga ditemukan data paragog, yaitu penguatan di akhir kata. Data berikut ini menunjukkan terjadinya proses fonologis paragog pada bahasa webinar. Data penelitian yang ditemukan terkait tipe perubahan bunyi ini tidak banyak dan kebanyakan berupa serapan dari bahasa Inggris. Penguatan atau penambahan bunyi [a], [ə], dan [u], pada bentuk asal suatu kata dapat mengubah struktur kata tersebut. Proses transformasi fonologis melalui paragog ini menunjukkan adanya karakteristik tertentu pada bahasa webinar. 
Penyisipan bunyi [w] dan [y] di tengah-tengah kata menunjukkan bahwa terjadi proses fonologis epentesis pada bahasa webinar. Istilah yang sangat familier adalah peluncuran (glinding). Proses transformasi fonologis melalui epentesis ini menunjukkan adanya karakteristik tertentu pada bahasa webinar.

Tabel 8. Peluncuran (Glinding)

\begin{tabular}{|c|c|c|c|}
\hline $\begin{array}{l}\text { Bentukan } \\
\text { Asal }\end{array}$ & & Peluncuran & Makna \\
\hline bantuan & $\rightarrow$ & [bantuwan] & sokongan \\
\hline bersua & $\rightarrow$ & & bertemu \\
\hline kedua & $\rightarrow$ & [kəduwa] & $\begin{array}{l}\text { bilangan } \\
\text { urutan }\end{array}$ \\
\hline keluar & $\rightarrow$ & [kəluwar] & $\begin{array}{l}\text { bergerak } \\
\text { menuju luar }\end{array}$ \\
\hline ketua & $\rightarrow$ & [kətuw & pemimpin \\
\hline kuasa & $\rightarrow$ & [kuw & $\begin{array}{l}\text { kesanggupa } \\
\mathrm{n}\end{array}$ \\
\hline $\begin{array}{l}\text { luaranny } \\
\text { a }\end{array}$ & $\rightarrow$ & $\begin{array}{l}\text { [luwaranña } \\
\text { ] }\end{array}$ & capaiannya \\
\hline membuat & $\rightarrow$ & $\begin{array}{l}\text { [mombuwat } \\
\text { ] }\end{array}$ & $\begin{array}{l}\text { Mengadaka } \\
\mathrm{n}\end{array}$ \\
\hline peluang & $\rightarrow$ & [pəluway] & kesempatan \\
\hline tujuan & $\rightarrow$ & [tuju & maksud \\
\hline ilmiah & $\rightarrow$ & [ilmiyah] & $\begin{array}{l}\text { bersifat } \\
\text { ilmu }\end{array}$ \\
\hline kiat & $\rightarrow$ & [ki] & cara \\
\hline kuliah & $\rightarrow$ & [kuliyah] & $\begin{array}{l}\text { belajar di } \\
\text { perguruan } \\
\text { tinggi }\end{array}$ \\
\hline media & $\rightarrow$ & [mediya] & alat \\
\hline niat & $\rightarrow$ & [niyat] & $\begin{array}{l}\text { maksud } \\
\text { perbuatan }\end{array}$ \\
\hline panitia & $\rightarrow$ & [panitiya] & $\begin{array}{l}\text { pelaku } \\
\text { kegiatan }\end{array}$ \\
\hline siap & $\rightarrow$ & [siyap] & $\begin{array}{l}\text { sudah } \\
\text { disediakan }\end{array}$ \\
\hline
\end{tabular}

Data penelitian di atas menunjukkan terjadinya penyisipan bunyi [w] di antara bunyi $[\mathrm{u}]$ dan [a]. Bunyi $[\mathrm{w}]$ termasuk bunyi semivokal labial. Selain itu, terjadinya penyisipan bunyi [y] di antara bunyi [i] dan [a]. Bunyi [y] termasuk bunyi semivokal palatal. Penyederhanaan kaidah transformasi perubahan bunyi pada kata-kata di atas sebagai berikut ini.

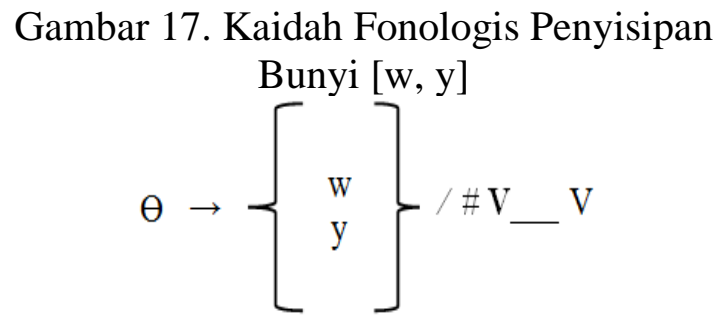

Pembacaan kaidah di atas adalah bunyi [w] dan [y] disisipkan di antara vokal [u] dan [a], juga di antara [i] dan [a] pada suku kata yang berbeda. Formulasi transformasi kaidah fonologisnya sebagai berikut ini.

Gambar 18. Kaidah Fonologis Penyisipan Bunyi [w, y] Berfitur [+son dan +kont]

$$
\Theta \rightarrow\left[\begin{array}{c}
\mathrm{K} \\
+\mathrm{son} \\
+\mathrm{kont}
\end{array}\right] / \# \mathrm{~V}-\mathrm{V}
$$

Selain penguatan di tengah kata, berikutnya di dalam penelitian ini juga ditemukan data paragog, yaitu penguatan di akhir kata. Data berikut ini menunjukkan terjadinya proses fonologis paragog pada bahasa webinar.

Data penelitian yang ditemukan terkait tipe perubahan bunyi ini tidak banyak dan kebanyakan berupa serapan dari bahasa Inggris. Penguatan atau penambahan bunyi [a], [ə], dan [u], Data penelitian yang ditemukan terkait tipe perubahan Kaidah fonologis penguatan juga terjadi di akhir kata. Contoh bunyi [a], [u], dan [ə] ditambahkan pada suku kata akhir. Status bunyi [a], [u], dan [ə] ini sebagai koda.

Pada bentuk asal suatu kata dapat mengubah struktur kata tersebut. Proses transformasi fonologis melalui paragog ini menunjukkan adanya karakteristik tertentu pada bahasa webinar. 
Tabel 9. Penguatan di Akhir Kata (Paragog)

\begin{tabular}{llll}
\hline $\begin{array}{l}\text { Bentukan } \\
\text { Asal }\end{array}$ & \multicolumn{1}{c}{ Paragog } & Makna \\
\hline $\begin{array}{l}\text { Norm } \\
\text { mutualism }\end{array}$ & $\rightarrow$ & [norma & Nilai \\
& & ] & \\
kapitalism & $\rightarrow$ & {$[$ kapitalisme } & kaum \\
$\mathrm{e}$ & & ] & pemilik \\
& & modal \\
lamp & $\rightarrow$ & {$[$ lampu $]$} & alat untuk \\
& & & menerang \\
& & i \\
pen & $\rightarrow$ & [pena] & alat tulis \\
\hline
\end{tabular}

Penyederhanaan kaidah transformasi perubahan bunyi pada kata-kata di atas sebagai berikut ini.

Gambar 19. Kaidah Fonologis Penambahan Bunyi [ə, a]<smiles>[X][In]C1CCC(C)CC1</smiles>

Pembacaan kaidah di atas adalah bunyi [ə] dan [a] ditambahkan sebelum konsonan pada suku kata yang pertama. Formulasi transformasi kaidah fonologisnya sebagai berikut ini.

Gambar 20. Kaidah Fonologis Penambahan Bunyi [ə, u, a] Berfitur Vokal Rendah dan Bulat

$$
\Theta \rightarrow\left[\begin{array}{c}
\mathrm{V} \\
+\mathrm{ren} \\
+ \text { bul }
\end{array}\right] / \mathrm{K}-\#
$$

Kaidah ini menyatakan bahwa bunyi [ə], [u], dan [a] berfitur sebagai vokal rendah dan bulat ditambahkan setelah konsonan akhir, status bunyi yang ditambahkan sebagai koda.

\section{Netralisasi}

Netralisasi termasuk bagian yang ditemukan dalam kajian fonologis generatif pada bahasa webinar. Netralisasi adalah suatu proses pengurangan perbedaan fonologis pada suatu lingkungan tertentu. Segmen-segmen yang berkontras dalam satu lingkungan mempunyai representasi yang sama dalam lingkungan nertralisasi. Netralisasi bunyi [d] $\rightarrow$ [t] terjadi pada kata wujUd, abad, covId, admin menjadi wujUt, abat, covIt, dan atmin. Bunyi [d] berubah menjadi [t] karena [d] berposisi sebagai koda dan tidak ada bunyi lain yang memengaruhi.

Netralisasi bunyi [b] $\rightarrow$ [p] terjadi pada kata $a r a b$, sub, sebab, wajIb menjadi arap, sub, sebab, dan wajip. Bunyi [b] berubah menjadi [p] karena [b] berposisi sebagai koda dan tidak ada bunyi lain yang memengaruhi. Bunyi $[\mathrm{b}]$ termasuk bilabial bersuara, sedangkan bunyi [p] termasuk bilabial tak bersuara. Oleh karena itu, bunyi [d] dan [b] yang bersuara itu, karena tidak ada pengaruh bunyi setelahnya atau posisi bunyi [d] dan [b] sebagai koda pada bentuk dasar maka berubah menjadi $[\mathrm{p}]$ dan $[\mathrm{t}]$ tak bersuara.

\section{Disimilasi}

Selain itu, disimilasi juga ditemukan dalam penelitian ini. Disimilasi merupakan perubahan yang terjadi bila dua bunyi yang sama berubah menjadi tak sama. Disimilasi terjadi jika terdapat dua bunyi yang sama karena berdekatan letaknya berubah menjadi tak sama. Disimilasi pada bahasa webinar ditunjukkan oleh deretan bunyi yang sama menjadi bunyi yang berbeda.

Deret konsonan /tt/ berubah menjadi /pt/, deret konsonan /jj/ berubah menjadi /rj/ dan /nj/. Disimilasi semacam ini berkecenderungan untuk menyederhanakan fonem-fonem yang sama di dalam suku kata yang satu dengan lainnya, atau antara morfem yang satu dengan morfem lainnya dalam satu kata, sehingga mengakibatkan fonem-fonem yang dimaksud menjadi tidak sama/berbeda. 
Terkait dengan proses pembentukan antarsatuan lingualnya, disimilasi dapat dibedakan menjadi dua, yaitu disimilasi fonologis, misalnya pada kata cipta, senjata, sarjana dan disimilasi morfologis, misalnya pada kata belajar.

Metatesis (metathesis) merupakan perubahan letak huruf, bunyi, atau suku kata dalam kata. Metatesis juga bisa disebut suatu proses perubahan bunyi yang berujud pertukaran tempat dua fonem. Dalam penelitian ditemukan bentukan kata metatesis yakni kata artikel dan googel. Kata artikel berasal dari bahasa Inggris article yang artinya tulisan.

Kata article setelah diserap ke dalam bahasa Indonesia terjadi pertukaran letak bunyi pada kata tersebut. Pertukaran itu tampak pada suku kata yang terakhir yakni \#cle berubah menjadi \#kel. Kata googel berasal dari bahasa Inggris google yang artinya refleksi dari kata googol. Kata google setelah diserap ke dalam bahasa Indonesia terjadi pertukaran letak bunyi pada kata tersebut. Pertukaran itu tampak pada suku kata yang terakhir yakni \#gle berubah menjadi \#kel.

\section{Proses Struktur Kata}

Struktur kata termasuk juga dalam kajian fonologis generatif ditemukan dalam kajian pada bahasa webinar. Perubahan struktur suku kata yang disebabkan oleh ruas-ruas yang lemah atau kuat dalam suatu kata atau morfem dapat disebut sebagai proses penguatan asalnya dengan kaidah-kaidah fonologis.

Terdapat 21 tipe struktur dalam penelitian ini, yakni: 1) tipe 1 \#KVK\#, misalnya kata sup, 2) tipe $2 \# \mathrm{~V}+\mathrm{KV} \#$ misalnya kata ama, 3) Tipe 3 \#V+KVK\# misalnya kata abat, 4) Tipe 4 \#VK+KVK\# misalnya kata ama, 5) Tipe 5 \#KV+KV\# pada kata tapi, 6) Tipe 6 \#KV+VK\# pada kata taUn, 7) Tipe 7 \#KVK+VK\# pada kata norma, 8) Tipe 8 \#KV+KVK\# pada kata sabap, 9) Tipe 9 \#KVK+KVK\# pada kata tumbuh, 10) Tipe $10 \# \mathrm{KV}+\mathrm{KV}+\mathrm{KV} \#$ pada kata pahala, 11)
Tipe 11 \#KV+KV+KVK pada kata tujuwan, 12) Tipe 12 \#KVK+KV+KV\# pada kata sarjana 13) Tipe 13 \#VK+KV+KVK\# pada kata ilmiyah, 14) Tipe 14 \#KV+KV+KVK\# pada kata bolajar, 15) Tipe 15 \#VK+ KV+KV\# pada kata asmara, 16) Tipe 16 \#KVK+V+KVK\# pada kata məyolah, 17) Tipe $17 \mathrm{KVK}+\mathrm{V}+\mathrm{KVKV}$ pada kata majalami, 18) Tipe 18 \#KV+KV+KV+KVK\# pada kata malakukan, 19) Tipe 19 $\# \mathrm{KV}+\mathrm{KV}+\mathrm{KVK}+\mathrm{KVK} \#$ pada kata mawajlbkan, 20) Tipe 20 \#KVK+KV+KVK+KVK\# pada kata mə引hasilkan, 21) Tipe 21 $\# \mathrm{KV}+\mathrm{KV}+\mathrm{KV}+\mathrm{KV}+\mathrm{KV} \#$ pada kata mamotivasi.

Berdasarkan hasil analisis data di atas, merepresentasikan bahwa fenomena kegiatan webinar dalam masyarakat memberikan dampak terhadap penggunaan bahasa, salah satunya pada proses fonologis. Artinya, penggunaan bahasa pada kegiatan tersebut memunculkan variasi fonologi yang digunakan oleh peserta tutur. Adanya fenomena tersebut, menarik untuk dikaji yang dapat memperkaya khazanah keilmuan, khususnya pada bidang linguistik.

Oleh karena itu, penelitian ini berusaha mendeskripsikan tipologi fonologi bahasa yang digunakan dalam kegiatan seminar keilmuan melalui web. Orang lebih sering menggunakan kosa kata web dibanding kosakata yang lebih lengkap. Web merupakan sebagian kata dari word wide web (www). Web berisi dokumen yang ditulis dalam format HTML (hyper text markup language), yang hampir semua informasi bisa diakses melalui http. Semua publikasi dari web tersebut dapat membentuk sebuah jaringan informasi yang sangat besar yang dapat diakses dengan menggunakan internet. Akhir-akhir ini istilah web ini disandingkan dengan istilah seminar 
sehingga menjadi webinar. Penyampaian informasi keilmuan melalui webinar ini tentu saja berbeda ketika kegiatan semacam ini dilaksanakan bersemuka.

Representasi fonetis penutur dalam memberi sambutan ataupun menyampaikan pendapat sangat beragam. Hal ini tentu saja banyak fator yang memengaruhinya baik yang bersifat internal maupun eksternal. Faktor internal misalnya kemampuan berbahasa penutur, kondisi psikologis, bawaan (inate), atau kurangnya berlatih berbicara di depan umum. Faktor eksternalpun juga berpengaruh terhadap produksi tuturan peserta dalam mengikuti webinar, misalnya jaringan terganggu, kedisiplinan dalam berkomunikasi ketika webinar berlangsung.

Chomsky

(1972:

mengemukakan bahwa kapasitas genetik manusia sejak lahir juga memengaruhi kemampuannya untuk memahami bahasa di sekitar sehingga hasilnya adalah sebuah konstruksi sistem bahasa yang tertanam dalam diri. Chomsky sangat populer ketika menghadirkan teori generatif transformasi yang merupakan teori paling modern dan menonjol ketika itu. Di dalam teori tersebut ditegaskan bahwa kemampuan akal, membicarakan masalah kebahasaan dan pemerolehannya, serta hubungannya dengan akal dan pengetahuan manusia menjadi sangat penting dalam berkomunikasi.

Terkait dengan pendapat Chomsky tersebut, penelitian ini bertujuan mendeskripsikan proses dan kaidah fonologis tuturan lisan peserta webinar bidang pendidikan. Penelitian memang cukup membutuhkan waktu untuk mengamati gejala-gejala perubahan bunyi dalam kegiatan webinar. Titik tekan penelitian ini pada pencarian varian perubahan bunyi dan perumusan kaidah, sehingga membutuhkan tenaga dan pikiran untuk mengamati satu-persatu perubahan bunyi. Kejelian dan kecermatan analisis data menjadi faktor penentu keberhasilan dalam merumuskan informasi yang inovatif perubahan bunyi pada bahasa webinar melalui kajian fonologi generatif.

Kajian bunyi bahasa ini menjadi penting karena bunyi bahasa merupakan bunyi yang dihasilkan oleh alat ucap manusia yang sewaktu-waktu dapat berubah. Oleh karena pengamatan bunyi bahasa berbeda dengan bunyi di dalam fisika atau ilmu lainnya. Bunyi bahasa sangat bersifat kreatif dan produktif. Bunyi bahasa yang dihasilkan oleh setiap penutur tentunya tidak selalu sama persis. Hal ini disebabkan oleh banyak faktor sebagaimana dikatakan Chomsky. Fonologi tidak dapat melukiskan sifatsifat, ciri-ciri bunyi yang dapat ditranskripsikan ke dalam satu lambang bunyi/huruf saja, tetapi bisa jadi bertambah alofonnya. Pendapat para pakar bahasa tentang istilah di dalam kajian fonologi generatif pun berbeda-beda, ada yang menyebut ciri-ciri pembeda, ada juga pakar yang menggunakan istilah fitur distingtif, ada yang mengatakan pelemahan da nada pula yang mengatakan penghilangan. Tentu hasil penelitian ini menarik untuk dibahas lebih lanjut.

Prosedur kerja (lihat Kenstowicz \& Kissenbert, 1979: 29; Wahab, 2005: 17) yang dapat dilakukan melalui model fonologi generatif sebagai berikut ini. Pertama, data rekaman suatu bahasa dapat dianalisis yang sebelumnya sudah ditentukan dulu hipotesis representasi dasar dari representasi fonetik yang ada. Hal ini ditempuh, karena fonologi generatif percaya bahwa beberapa aspek realisasi fonetik suatu morfem merupakan ciri idiosinkratik dari morfem itu, sedang aspek realisasi yang lain mengikuti prinsip keteraturan yang sistemik.

Kedua, sesudah hipotesis mengenai representasi dasar ditentukan, dicari aturan-aturan yang dapat mengubah representasi dasar menjadi fonetik. 
Aturan-aturan yang disusun itu harus diaplikasikan kepada data yang tersedia. Hipotesis-hipotesis diversifikasi untuk memperoleh hipotesis yang paling bisa diterima. Setelah itu dapat disimpulkan sistem fonologi bahasa itu.

Ketiga, postulasi aturan-aturan di atas dilakukan dalam rangka membedakan ciri ucapan yang kontrastif (pemberian konteks akan membuat apa yang muncul tidak dapat diperkirakan) dan nonkontrastif (pemberian konteks membuat apa yang muncul dapat diperkirakan). Pembedaan konstrastif dan nonkontrastif ini bertujuan alternasi (adanya dua varian atau lebih, baik distingtif maupun tidak dalam suatu hubungan paradigmatik). Prosedur tersebut dilakukan agar proses dan kaidah fonologi bahasa webinar bidang pendidikan dapat dideskripsikan, sehingga hasilnya diharapkan dapat digunakan untuk pengembangan teori-teori linguistik khususnya bidang fonologi.

Schane (1973: 49) menjelaskan bahwa fonologi generatif membicarakan proses-proses dan kaidah-kaidah fonologis. Schane mengklasifikasikan proses fonologi menjadi empat macam yakni: 1) asimilasi, 2) struktur kata, 3) pelemahan dan penguatan, serta 4) netralisasi. Sementara itu, Yulianto (2019, hal. 35) menggolongkan proses fonologis yang terjadi pada tuturan anak menjadi empat, yaitu 1) proses substitusi meliputi: penghambatan (stopping), pengedepanan (fronting), peluncuran (glinding), vokalisasi (vocalization), dan netralisasi vokal (wovel neutralization), 2) proses asimilasi meliputi: penyuaraan (voicing), harmonisasi konsonan (consonant harmonization), dan asimilasi vokal progresif (progressive wovel assimilation), dan 3) proses struktur silabis meliputi: reduksi kluster, penghilangan konsonan akhir, penghilangan suku tak bertekanan, dan reduplikasi.
Dengan menggunakan metode deskriptif kualitatif dan analisis data model Mile Huberman, hasil penelitian ini menghasil dua hal penting terkait proses dan kaidah fonologi bahasa webinar. Proses fonologi yang ditemukan, yakni 1) asimilasi parsial, total, regresif, dan langsung, 2) pelemahan meliputi: apheresis, sinkop, dan apokop, 3) penguatan meliputi: protesis, epentesis, paragog, dan peluncuran, 4), netralisasi, 5) disimilasi, 6) metatesis, dan 7) proses struktur kata. Keenam temuan tersebut merupakan cerminan diterapkannya analisis fitur distingtif dan fitur nondistingtif.

Adapun kaidah fonologi yang ditemukan meliputi: 1) kaidah perubahan fitur yakni perumusan penyederhanaan dan formulasi perubahan fitur bunyi bersuara, 2) kaidah pelemahan bunyi yang meliputi perumusan penyederhanaan dan fomulasi perubahan bunyi aferesis, sinkop, dan apokop, 3) kaidah penguatan bunyi yang meliputi perumusan penyederhanaan dan fomulasi perubahan bunyi protesis, epentesis, paragog, dan peluncuran, 4) kaidah asimilasi yang meliputi perumusan penyederhanaan dan formulasi perubahan bunyi langsung dan parsial, dan 5) kaidah disimilasi.

Temuan penelitian ini sangat penting terutama untuk pengembangan teori, metode analisis, dan penerapan kajian fonologi generatif dalam bidang Linguistik atau pun Fonologi. Kesulitan pemahaman fitur distingtif dan penentuan notasi untuk membedakan fitur banyak dialami oleh masyarakat bahasa. Kajian terhadap teori dan pemekaran kosa kata bahasa Indonesia hendaknya menjadi pusat kajian yang menyenangkan dan berdampak sebagai sebagai bahan pertimbangan di dalam pembentukan kosakata bahasa Indonesia baik secara lisan ataupun tulis.

Hasil analisis perubahan bunyi bahasa webinar secara lisan ini diharapkan memberikan manfaat praktis untuk keperluan pembelajaran bahasa Indonesia di 
sekolah atau pun untuk penelitian lanjutan. Dengan demikian, bahasa Indonesia dapat berposisi sebagai bahasa cendekia. Sakri (1993: 123) mengemukakan sejumlah cendekiawan berusaha untuk membina Bahasa Indonesia sehingga bahasa itu menjadi lebih lengkap dan lebih mantap sebagai bahasa kecendekiaan. Kelengkapan dan kemantapan itu terletak pada kata atau istilah serta pada ungkapan atau untaian kata (baik frasa maupun kalimat). Selain itu, pemeliharaan keutuhan bahasa Indonesia perlu dilakukan. Paling sedikit ada dua hal yang perlu diperhatikan di dalam pemeliharaan bahasa ini. Hal pertama adalah pembakuan serta hal kedua adalah norma.

Terkait pembakuan dan norma sebagaimana pendapat Sakri di atas, hasil penelitian mengenai asimilasi dan metatesis banyak ditemukan yang varian bunyinya sangat banyak dan itupun masih bisa bertambah banyak jika dilakukan kajian ke webinar-webinar lainnya. Temuan asimilasi dari serapan bahasa Asing terutama bahasa Inggris lebih banyak merumuskan pola, misalnya akhiran kata bahasa Inggris migration dan tradition setelah diserap ke dalam bahasa Indonesia menjadi migrasi dan tradisi. Kata bahasa Inggris google dan simple setelah diserap ke dalam bahasa Indonesia menjadi googel (pelafalan) dan simpel.

Hasil penelitian ini juga dapat memberikan gambaran mengenai penggunaan kata-kata secara lisan. Untuk itu, hasil penelitian ini dapat dipakai sehingga bahan perbandingan untuk mengetahui kata mana yang tergolong baku atau tidak. Hal ini juga mencakup perluasan kata bahasa Indonesia. Kridalaksana (1986: 461) mengemukakan perluasan kata itu juga mencakup kegiatankegiatan seperti 1) mencari arti kata yang tepat di dalam kamus yang baik, 2) mencatat bagaimana mengucapkan kata itu dan mengulangi berkali-kali sehingga kata itu termasuk khazanah kosakata kita yang fungsional, 3) mengadakan perbandingan, 4) melihat kesamaan dan kelainan, dan 5) memelajari etimologi kata.

Hasil penelitian mengenai proses dan kaidah fonologi pada bahasa webinar ini juga dapat dipakai untuk mengetahui kompetensi linguistik peserta webinar. Kompetensi linguistik merupakan pengetahuan yang dimiliki oleh seorang penutur tentang bahasanya, termasuk juga di sini kemampuan seseorang untuk menguasai kaidah-kaidah yang berlaku bagi bahasanya. Performansi linguistis dalam webinar inipun, keterampilan pesertanya dapat diketahui. Dengan demikian, memelajari materi bahasa Indonesia pada unsur terkecil ini penting dilakukan agar kita semua mampu melafalkan kosakata sesuai dengan kaidah yang ditetapkan.

\section{KESIMPULAN}

Terdapat dua hal yang dapat disimpulkan dalam tulisan ini, yakni terkait dengan proses dan kaidah fonologi bahasa webinar bidang pendidikan.

Pertama, proses fonologis dalam kajian fonologi generatif ini bertujuan menggambarkan pengetahuan yang dimiliki oleh penutur asli untuk dapat menghasilkan dan memahami tata bunyi bahasa mereka yang dapat diketahui melalui representasi fonetis. Proses fonologi yang ditemukan dalam penelitian ini meliputi: 1) asimilasi parsial, total, regresif, dan langsung, 2) pelemahan meliputi: aferesis, sinkop, dan apokop, 3) penguatan meliputi: protesis, epentesis, paragog, dan peluncuran, 4), netralisasi, 5) disimilasi, 6) metatesis, dan 7) proses struktur kata. Keenam temuan tersebut merupakan cerminan diterapkannya analisis fitur distingtif dan fitur nondistingtif.

Kedua, perubahan fitur dalam penelitian ini terjadi karena pengaruh bunyi di lingkungannya. Terdapat tiga hal 
dalam perubahan ciri/fitur, yakni (1) segmen/unsur mana yang berubah, (2) bagaimana segmen itu berubah, dan (3) dalam kondisi apa segmen itu berubah. Adapun kaidah fonologi meliputi: 1) kaidah perubahan fitur yakni perumusan penyederhanaan dan formulasi perubahan fitur bunyi bersuara, 2) kaidah pelemahan bunyi yang meliputi perumusan penyederhanaan dan fomulasi perubahan bunyi aferesis, sinkop, dan apokop, 3) kaidah penguatan bunyi yang meliputi perumusan penyederhanaan dan fomulasi perubahan bunyi protesis, epentesis, paragog, dan peluncuran, 4) kaidah asimilasi yang meliputi perumusan penyederhanaan dan formulasi perubahan bunyi langsung dan parsial, dan 5) kaidah disimilasi.

\section{DAFTAR PUSTAKA}

Astini, N. K. S. (2020). Tantangan Dan Peluang Pemanfaatan Teknologi Informasi Dalam Pembelajaran Online Masa Covid-19. Cetta: Jurnal Ilmu Pendidikan, 3(2), 241-255.

Chomsky, N. (1972). Language and Mind. New York: Harcourt Brace.

Dani, J. A., \& Mediantara, Y. (2020). Covid-19 Dan Perubahan Komunikasi Sosial. Persepsi, 3(1), 94-102.

Kenstowicz, M., \& Kissenbert, C. (1979). Generative Phonology: Descriptive and Theory. New York: Academic Press. Inc.

Kridalaksana, H. (1986). Pengembangan Ilmu Bahasa dan Pembinaan Bangsa. Ende-Flores: Penerbit Nusa Indah.

Lyons, J. (1984). Language and Linguistics. London: Cambridge University Press.

Nafisah, S. (2017). Proses Fonologis dan
Pengkaidahannya dalam Kajian Fonologi Generatif. Deiksis, 9(1), 70-78.

Sakri, A. (1993). Ilmuwan dan Bahasa Indonesia. Bandung: Penerbit ITB.

Schane, S. A. (1973). Generative Phonology. New Jersey: Prentice Halle.

Sela, A. W., \& Nurhayati, N. (2020). Proses Asimilasi pada Bahasa Sumbawa: Fonologi Generatif. Parafrase, 20(1), 9-13.

Setiana, L. N., Supriyatno, T., \& Rahayu, P. (2021). Inovasi Pembelajaran Bahasa Indonesia Daring Berbasis Mini Webinar. Metamorfosa, 9(1), $1-13$.

Suparno. (2002). Dasar-dasar Linguistik Umum. Yogyakarta: Tiara Wacana.

Tarmini, W., Safi'i, I., Witdianti, Y., \& Larassaty, S. (2020). Peningkatan Kompetensi Profesional Guru Melalui Webinar Evaluasi Hasil Belajar Bagi Guru-Guru Mts. AlMa'arif 1 Aimas. Transformasi: Jurnal Pengabdian Masyaraka, 16(1), 53-62.

Wahab, A. (2005). Butir-Butir Linguistik. Surabaya: Air Langga University Press.

Wibowo, B. R., Sudan, D., \& Wirza, Y. (2020). Pemanfaatan Webinar Sebagai Media dalam Pembelajaran Kemampuan Berbicara untuk Pembelajar Dewasa di Indonesia. Jurnal Penelitian Pendidikan, 20(3), 417-431.

Yule, G. (1996). Pragmatics. New York: OUP Oxford.

Yulianto, B. (2019). Teori dan Aplikasi Fonologi Generatif. Gersik: Graniti. 